\title{
Corrigendum
}

\section{The RING ubiquitin E3 RNF114 interacts with A20 and modulates NF- $\kappa$ B activity and T-cell activation}

MS Rodriguez, I Egaña, F Lopitz-Otsoa, F Aillet, MP Lopez-Mato, A Dorronsoro, S Lobato-Gil, JD Sutherland, R Barrio, $C$ Trigueros and $\mathrm{V}$ Lang

Cell Death and Disease (2014) 5, e1520; doi:10.1038/cddis.2014.491; published online 13 November 2014

Correction to: Cell Death and Disease (2014) 5, e1399; doi:10.1038/cddis.2014.366; published online 28 August 2014

Since the publication of this article it has been noted that the name of A Dorronsoro was incorrect. This has now been rectified and the corrected article together with this corrigendum appears online.

The authors would like to apologize for any inconvenience this may have caused. 